\title{
UBEZPIECZENIE JAKO FORMA ZABEZPIECZENIA KREDYTU
}

Agata Szczukocka dr hab. prof. nadzw. UŁ, Katedra Metod Statystycznych, Wydział Ekonomiczno-Socjologiczny, Uniwersytet Łódzki

\section{Wprowadzenie}

Podstawą działalności banku jest osiąganie zysku, a jednym ze sposobów uzyskiwania dochodów jest udzielanie kredytów. Kredyt tak jak każda działalność człowieka jest obarczony ryzykiem. W celu minimalizacji tego ryzyka banki stosują różne formy zabezpieczeń. Jedną z metod zabezpieczenia spłaty kredytu jest ubezpieczenie. Istnieje możliwość ubezpieczenia od utraty pracy, zdrowia czy śmierci. Zadaniem ubezpieczenia jest ułatwienie spłaty rat lub całości kredytu w sytuacji zajścia nieprzewidzianych zdarzeń. Celem artykułu jest analiza sytuacji na rynku kredytowym i zwrócenie uwagi na jedną z form zabezpieczenia spłaty kredytów jaką jest ubezpieczenie. Do analiz zostały wykorzystane dane Urzędu Komisji Nadzoru Finansowego oraz Głównego Urzędu Statystycznego.

\section{Analiza rynku kredytowego w Polsce}

Zgodnie z artykułem 69 prawa bankowego przez umowę kredytu bank zobowiązuje się oddać do dyspozycji kredytobiorcy na czas oznaczony w umowie kwotę środków pieniężnych z przeznaczeniem na ustalony cel, a kredytobiorca zobowiązuje się do korzystania z niej na warunkach określonych w umowie, zwrotu kwoty wykorzystanego kredytu wraz z odsetkami w oznaczonych terminach spłaty oraz zapłaty prowizji od udzielonego kredytu. Umowa kredytowa m.in. powinna zawierać sposób spłaty kredytu. W 2015 roku w Polsce działalność bankową prowa- 
dziło 626 podmiotów, w porównaniu z rokiem 2010 nastąpił 3\% spadek, niemniej jednak analizując kolejne lata możemy mówić o pewnej stabilności sektora bankowego. Podobna sytuacja miała miejsce w przypadku zatrudnionych w instytucjach bankowych - tu także miał miejsce około $3 \%$ spadek. Wzrosła natomiast liczba oddziałów instytucji kredytowych.

\begin{tabular}{|l|r|r|r|r|r|r|}
\hline \multicolumn{1}{|c|}{ Wyszczególnienie } & \multicolumn{1}{|c|}{2010} & \multicolumn{1}{|c|}{2011} & 2012 & 2013 & 2014 & 2015 \\
\hline $\begin{array}{l}\text { Liczba podmiotów } \\
\text { prowadzących działalność } \\
\text { bankową }\end{array}$ & 646 & 642 & 642 & 640 & 631 & 626 \\
\hline $\begin{array}{l}\text { - banki komercyjne } \\
\text { - oddziały instytucji kredyto- } \\
\text { wych }\end{array}$ & 49 & 47 & 45 & 41 & 38 & 38 \\
\hline - banki spółdzielcze & 576 & 574 & 572 & 571 & 565 & 561 \\
\hline $\begin{array}{l}\text { Zatrudnienie w instytucjach } \\
\text { bankowych }\end{array}$ & 176916 & 176658 & 175071 & 174321 & 172659 & 170935 \\
\hline
\end{tabular}

Tabela 1. Liczba podmiotów i zatrudnienia w sektorze bankowym w latach 2010-2015 Źródło: Raport o sytuacji banków w roku 2013, 2014, 2015.

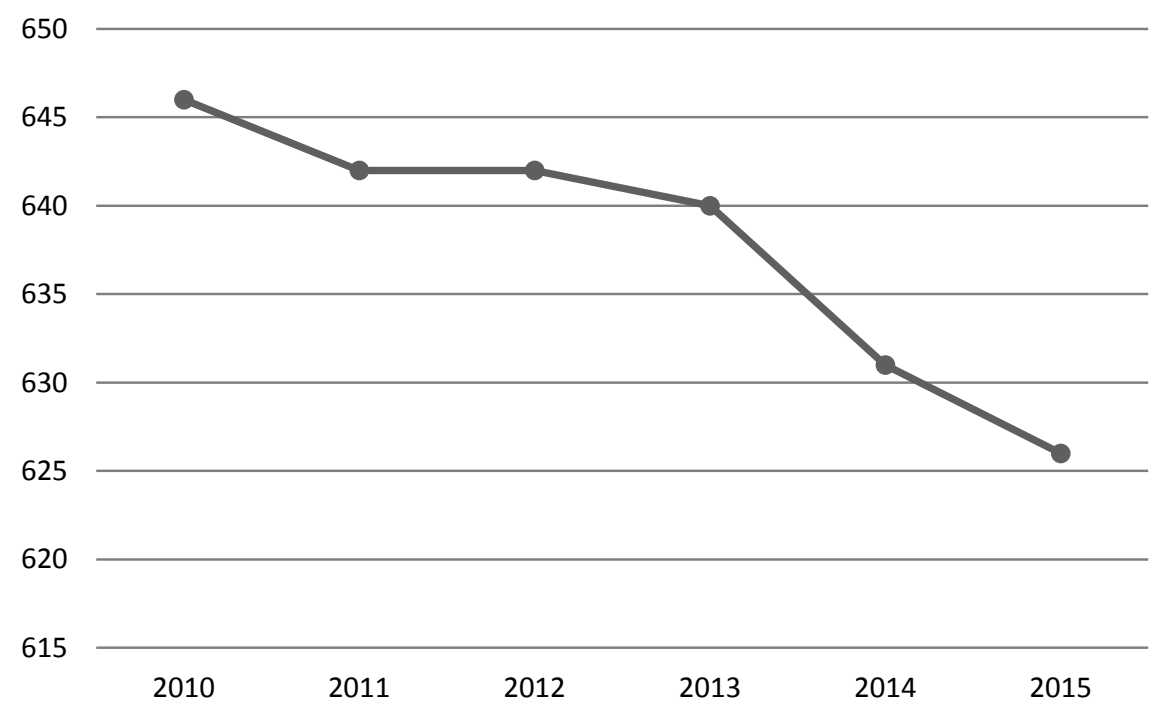

Rysunek 1. Liczba podmiotów prowadzących działalność bankową w latach 2010-2015

Źródło: opracowanie własne na podstawie Raport o sytuacji banków w roku 2013, 2014, 2015. 


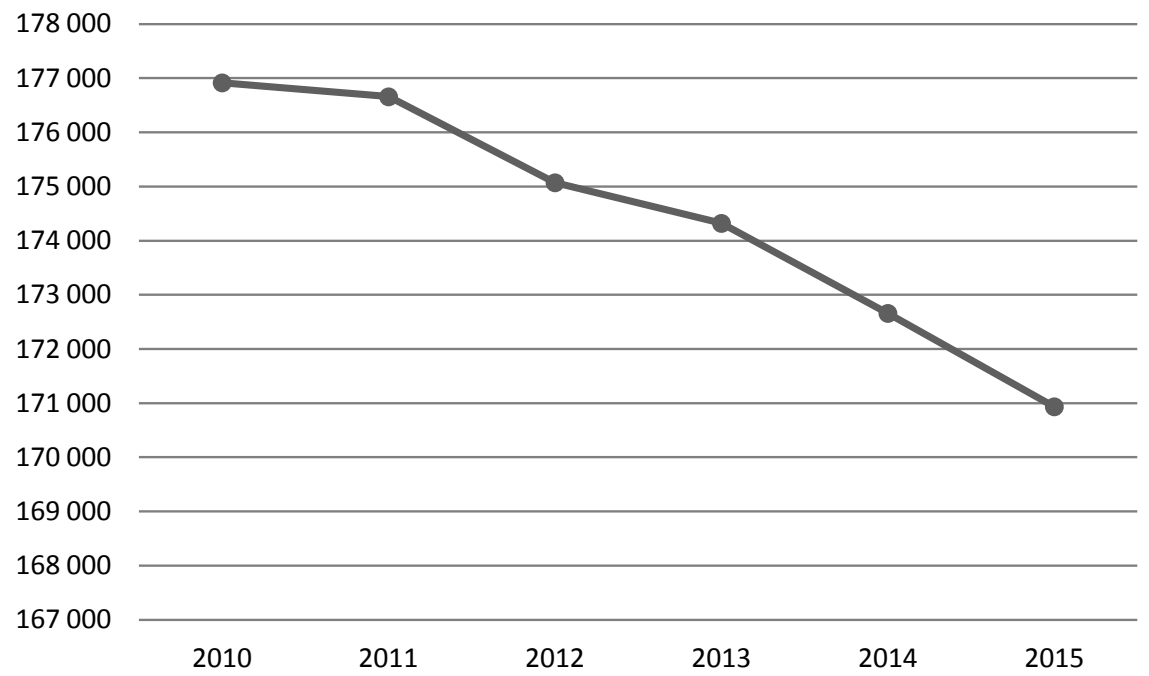

Rysunek 2. Zatrudnienie w instytucjach bankowych w latach 2010-2015 Źródło: opracowanie własne na podstawie Raport o sytuacji banków w roku 2013, 2014, 2015.

\begin{tabular}{|l|r|r|r|r|r|r|}
\hline \multicolumn{1}{|c|}{ Wyszczególnienie } & $11 / 10$ & $12 / 11$ & $13 / 12$ & $14 / 13$ & $15 / 14$ & $15 / 10$ \\
\hline Kredyty ogółem & 115,7 & 102,6 & 103,9 & 107,3 & 107,2 & 142 \\
\hline 1. Sektor finansowy & 101,2 & 127,1 & 125,9 & 132,2 & 112,3 & 240 \\
\hline 2. Sektor niefinansowy & 114,6 & 101,2 & 103,4 & 106,9 & 107,4 & 138 \\
\hline - gospodarstwa domowe & 111,9 & 100,2 & 104,0 & 106,2 & 106,7 & 132 \\
\hline - przedsiębiorstwa & 120,4 & 102,9 & 102,1 & 108,2 & 108,8 & 149 \\
\hline - instytucje niekomercyjne & 123,5 & 116,7 & 108,2 & 105,7 & 107,1 & 176 \\
\hline 3. Sektor budżetowy & 133,8 & 108,5 & 100,9 & 100,3 & 102,4 & 150 \\
\hline $\begin{array}{l}\text { wg waluty: } \\
\text { - złote }\end{array}$ & 113,1 & 109,0 & 105,7 & 108,3 & 107,9 & 152 \\
\hline - waluty & 121,4 & 90,0 & 99,6 & 105,0 & 105,4 & 120 \\
\hline
\end{tabular}

Tabela 2. Dynamika portfela kredytowego Źródło: obliczenia własne na podstawie Raport o sytuacji banków w roku 2013, 2014, 2015.

W roku 2015 w porównaniu z rokiem 2010 nastąpił znaczny wzrost zapotrzebowania na kredyty (por tab. 2) zarówno w przypadku kredytów dla gospodarstw domowych (wzrost o 32\%), przedsiębiorstw (wzrost o 49\%) jak i instytucji niekomercyjnych (wzrost o 76\%). Uwage zwraca sektor budżetowy, w którym zainteresowanie kredytami w roku 2015 w porównaniu z rokiem 2014 było niewielkie (około $2 \%$ ), podobna sytua- 
cja miała miejsce w latach wcześniejszych (0,3\%). Z danych GUS wynika, że w ostatnim czasie przybywa osób młodych obciążonych zaległościami. W Polsce żyje 9298873 osób w wieku od 18 do 32 lat, przy czym 523804 spośród nich posiada zaległości wynoszące łącznie 3,7 mld zł, przy czym pod koniec 2016 roku liczba młodych ludzi z problemami finansowymi zwiększyła się o około 110 tys.

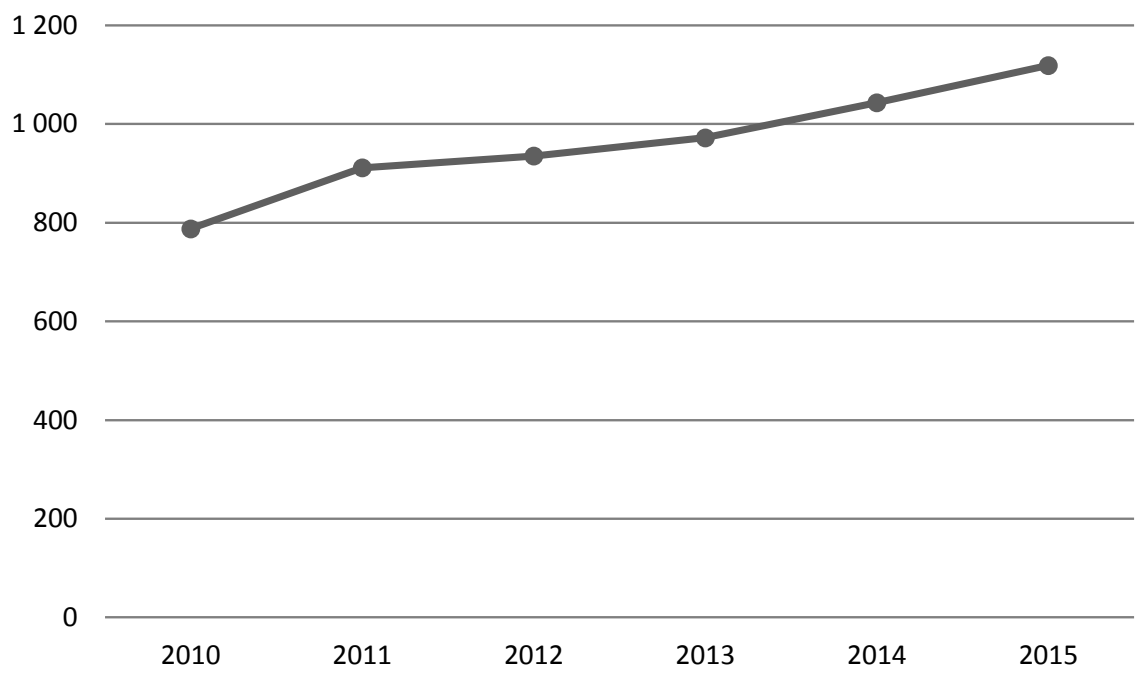

Rysunek 3. Kredyty ogółem

Żródło: opracowanie własne na podstawie Raport o sytuacji banków w roku 2013, 2014, 2015.

W 2015 roku kredyty mieszkaniowe stanowiły 60,7\% ogółu kredytów, kredyty konsumpcyjne $22,3 \%$, a $17 \%$ przypadało na pozostałe. W przypadku kredytów dla gospodarstw domowych, w roku 2015 obserwujemy wzrost o około 6\%, podobnie jak w roku 2014. Porównując sytuację na rynku kredytów mieszkaniowych i konsumpcyjnych, nieco większy wzrost był po stronie kredytów mieszkaniowych (por. tab. 3). Tendencję spadkową obserwujemy wśród kredytów walutowych. Spadek zainteresowania obserwujemy także wśród kredytów samochodowych.

W ostatnich dwóch latach nastąpiło pewnego rodzaju ożywienie na rynku kredytów dla przedsiębiorstw (por. tab. 4). W roku 2015 kredyty dla dużych przedsiębiorstw stanowiły 43\% ogółu kredytów, a 57\% to kredyty dla MSP. Największym zainteresowaniem cieszyły się kredyty operacyjne oraz inwestycyjne. 


\begin{tabular}{|l|r|r|r|r|r|r|}
\hline \multicolumn{1}{|c|}{ Wyszczególnienie } & $11 / 10$ & $12 / 11$ & $13 / 12$ & $14 / 13$ & $15 / 14$ & $15 / 10$ \\
\hline Ogółem & 111,9 & 100,2 & 104,0 & 106,2 & 106,7 & 132,2 \\
\hline 1. Kredyty mieszkaniowe & 119,3 & 100,9 & 104,3 & 106,0 & 107,1 & 142,5 \\
\hline - złotowe & 123,4 & 118,4 & 116,4 & 114,0 & 111,3 & 215,9 \\
\hline - walutowe & 116,8 & 90,1 & 94,6 & 98,1 & 102,3 & 100,0 \\
\hline 2. Konsumpcyjne & 97,2 & 94,7 & 102,4 & 104,2 & 106,5 & 104,5 \\
\hline - karty kredytowe & 91,8 & 93,3 & 96,8 & 104,1 & 103,1 & 89,1 \\
\hline - samochodowe & 88,3 & 83,8 & 84,2 & 87,5 & 95,2 & 51,9 \\
\hline - ratalne & 98,9 & 106,5 & 102,2 & 104,6 & 109,6 & 123,5 \\
\hline - pozostałe & 98,2 & 87,7 & 105,5 & 105,2 & 105,4 & 100,8 \\
\hline 3. Pozostałe & 111,9 & 106,5 & 105,1 & 109,5 & 105,5 & 144,8 \\
\hline - operacyjne & 116,3 & 114,4 & 111,3 & 112,8 & 108,7 & 181,5 \\
\hline - inwestycyjne & 114,7 & 100,0 & 105,6 & 104,3 & 104,1 & 131,5 \\
\hline - nieruchomości & 108,6 & 109,1 & 105,2 & 105,9 & 104,7 & 138,3 \\
\hline - pozostałe należności & 103,4 & 103,9 & 94,1 & 114,8 & 102,0 & 118,4 \\
\hline Według waluty & 109,2 & 107,5 & 109,4 & 109,9 & 108,7 & 153,4 \\
\hline - złote & 116,2 & 89,5 & 94,3 & 98,5 & 102,2 & 98,8 \\
\hline - waluty & & & & & \\
\hline
\end{tabular}

Tabela 3. Dynamika kredytów dla gospodarstw domowych Źródło: obliczenia własne na podstawie Raport o sytuacji banków w roku 2013, 2014, 2015.

\begin{tabular}{|l|r|r|r|r|r|r|}
\hline \multicolumn{1}{|c|}{ Wyszczególnienie } & $11 / 10$ & $12 / 11$ & $13 / 12$ & $14 / 13$ & $15 / 14$ & $15 / 10$ \\
\hline Ogółem & 120,4 & 102,9 & 102,1 & 108,2 & 108,8 & 149,0 \\
\hline 1. MSP & 125,2 & 103,6 & 99,5 & 107,1 & 106,0 & 146,5 \\
\hline - operacyjne & 124,5 & 108,3 & 94,7 & 106,1 & 104,8 & 142,0 \\
\hline - inwestycyjne & 134,9 & 99,4 & 107,0 & 105,5 & 108, & 164,2 \\
\hline - nieruchomości & 114,0 & 105,3 & 97,1 & 104,7 & 103,3 & 126,0 \\
\hline - pozostałe należności & 134,0 & 93,7 & 102,3 & 125,0 & 109,4 & 175,5 \\
\hline 2. Duże przedsiębiorstwa & 113,8 & 101,8 & 106,1 & 109,9 & 112,0 & 152,3 \\
\hline - operacyjne & 108,4 & 98,3 & 106,8 & 99,6 & 112,8 & 127,8 \\
\hline - inwestycyjne & 361,4 & 94,2 & 106,1 & 117,0 & 104,9 & 443,6 \\
\hline - nieruchomości & 91,3 & 109,5 & 95,7 & 95,5 & 159,5 & 145,7 \\
\hline - pozostałe należności & 138,0 & 131,5 & 110,8 & 129,7 & 110,4 & 288,0 \\
\hline $\begin{array}{l}\text { Według waluty } \\
\text { - złote }\end{array}$ & 116,8 & 108,2 & 99,6 & 104,8 & 107,8 & 142,3 \\
\hline - waluty & 131,1 & 88,7 & 110,4 & 118, & 111,3 & 169,2 \\
\hline
\end{tabular}

Tabela 4. Dynamika kredytów dla przedsiębiorstw Źródło: obliczenia własne na podstawie Raport o sytuacji banków w roku 2013, 2014, 2015. 


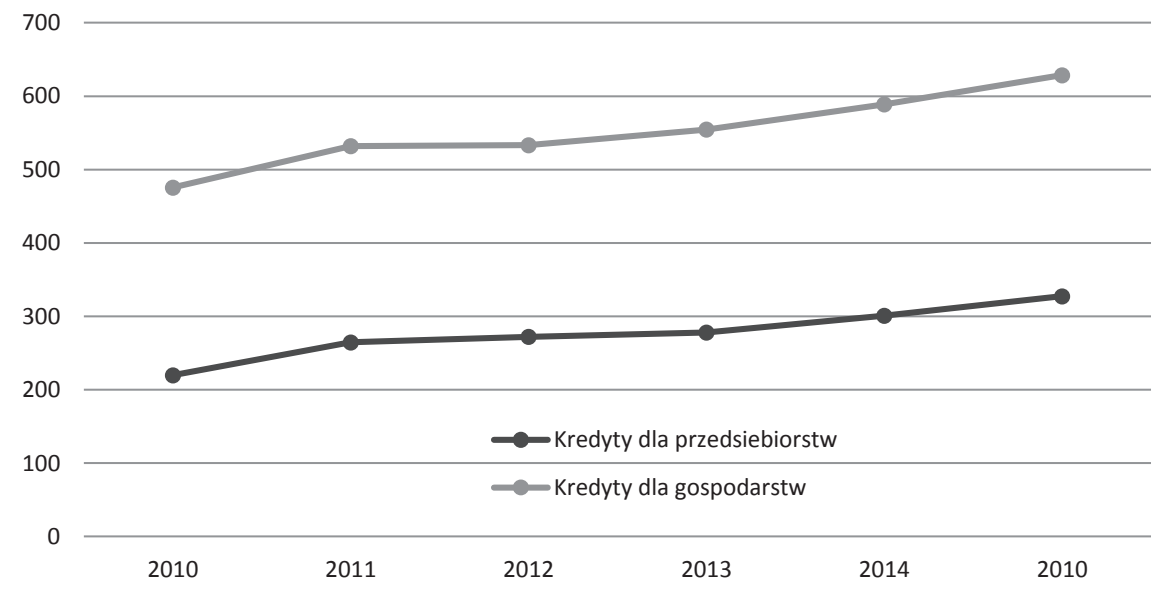

Rysunek 4. Kredyty dla gospodarstw domowych i przedsiębiorstw

Źródło: opracowanie własne na podstawie Raport o sytuacji banków w roku 2013, 2014, 2015.

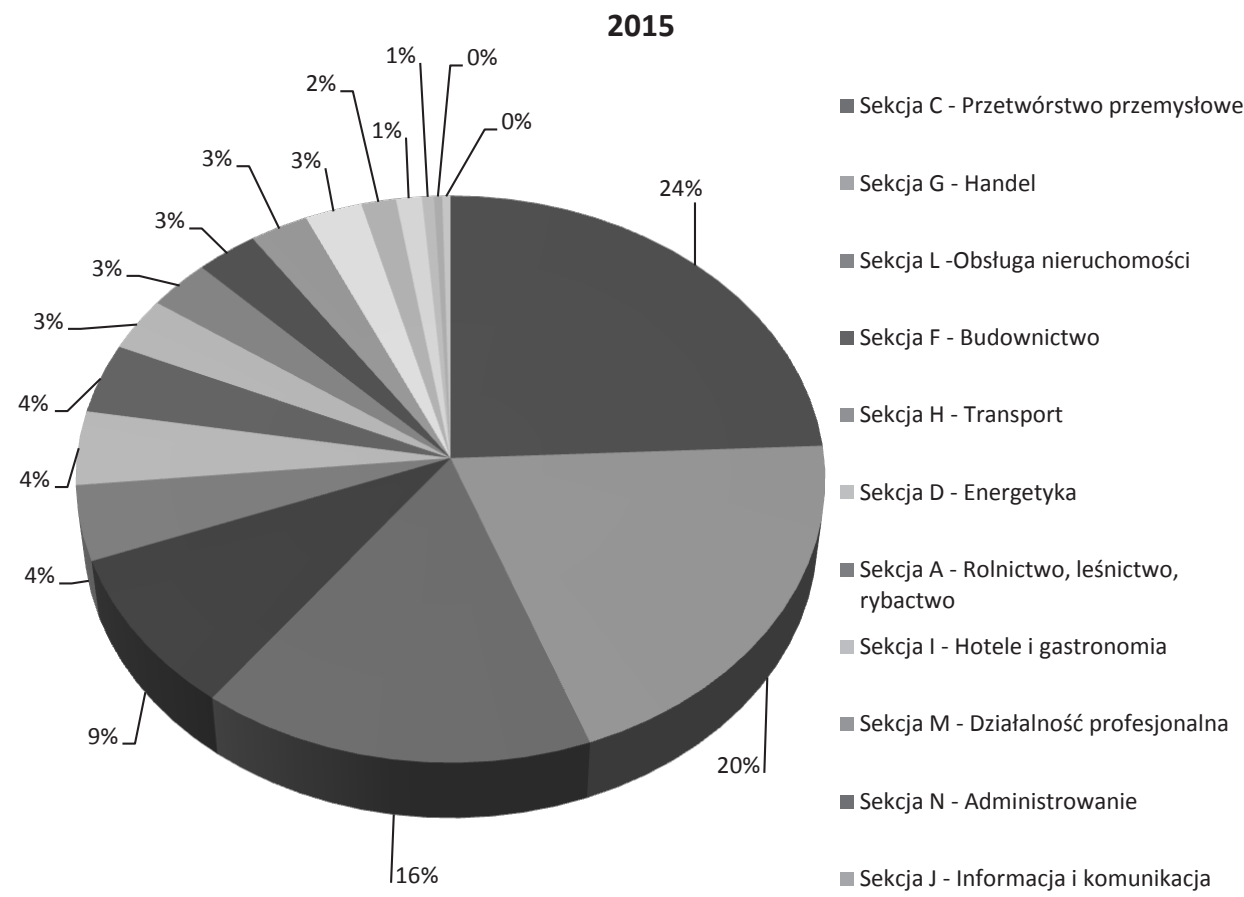

Rysunek 5. Struktura branżowa kredytów

Źródło: opracowanie własne na podstawie Raport o sytuacji banków w roku 2013, 2014, 2015. 
Analizując strukturę udzielanych kredytów pod względem branży zauważamy dominacje kredytów udzielanych przedsiębiorstwom przetwórstwa przemysłowego (sekcja C). Kredyty te stanowią około $24 \%$ kredytów sektora usług, następnie kredyty dla handlu, których udział wynosi około 20\%, na kolejnych miejscach znajdują się kredyty dla obsługi nieruchomości (16\%) i budownictwa (9\%). W roku 2015 w porównaniu z rokiem $2011 \mathrm{w}$ większości sekcji nastąpiło duże zainteresowanie kredytami (por. tab. 5).

\begin{tabular}{|l|r|r|r|r|r|}
\hline \multicolumn{1}{|c|}{ Wyszczególnienie } & $12 / 11$ & $13 / 12$ & $14 / 13$ & $15 / 14$ & $15 / 11$ \\
\hline Sekcja C - Przetwórstwo przemysłowe & 97,8 & 111,2 & 99,7 & 113,8 & 123,5 \\
\hline - spożywczy & 103,9 & 104,4 & 100,6 & 114,4 & 124,8 \\
\hline - chemiczny i farmaceutyczny & 105,5 & 118,8 & 95,6 & 108,3 & 129,7 \\
\hline - metalurgiczny & 102,1 & 105,1 & 101,9 & 110,5 & 120,8 \\
\hline - drzewny i papierniczy & 98,6 & 91,7 & 101,5 & 111,9 & 102,7 \\
\hline - maszynowy & 96,7 & 115,5 & 95,5 & 117,2 & 125,0 \\
\hline - rafinerie i koksownictwo & 102,6 & 157,5 & 104,8 & 109,1 & 184,6 \\
\hline - produkcja sprzętu transportowego & 69,1 & 75,0 & 104,8 & 131,8 & 71,6 \\
\hline -inna produkcja, naprawa maszyn & 102,8 & 140,5 & 92,3 & 116,7 & 155,6 \\
\hline - produkcja cementu, gipsu, szkła & 96,3 & 153,8 & 105,0 & 116,7 & 181,5 \\
\hline - produkcja tekstyIna & 93,8 & 120,0 & 100,0 & 105,6 & 118,8 \\
\hline Sekcja G - Handel & 103,0 & 124,9 & 99,4 & 108,2 & 138,3 \\
\hline Sekcja L - Obsługa nieruchomości & 99,5 & 109,0 & 114,6 & 103,0 & 128,1 \\
\hline Sekcja F - Budownictwo & 104,4 & 99,1 & 86,2 & 109,3 & 97,5 \\
\hline Sekcja H - Transport & 130,4 & 172,6 & 104,0 & 111,5 & 260,7 \\
\hline Sekcja D - Energetyka & 118,0 & 188,9 & 86,8 & 122,0 & 236,1 \\
\hline Sekcja A - Rolnictwo, leśnictwo, rybactwo & 117,3 & 128,4 & 101,6 & 109,7 & 167,9 \\
\hline Sekcja I - Hotele i gastronomia & 100,0 & 161,0 & 105,3 & 105,0 & 178,0 \\
\hline Sekcja M - Działalność profesjonalna & 105,7 & 203,6 & 72,8 & 119,3 & 186,8 \\
\hline Sekcja N - Administrowanie & 105,3 & 120,0 & 83,3 & 122,5 & 128,9 \\
\hline Sekcja J - Informacja i komunikacja & 107,4 & 129,9 & 98,2 & 83,8 & 114,8 \\
\hline Sekcja B - Górnictwo i wydobywanie & 171,4 & 183,3 & 90,9 & 151,7 & 433,3 \\
\hline Sekcja Q - Opieka zdrowotna & 110,3 & 116,3 & 100,0 & 110,0 & 141,0 \\
\hline Sekcja E - Dostawa wody, ścieki, odpady & 110,0 & 154,5 & 102,9 & 117,1 & 205,0 \\
\hline Sekcja R - Kultura, rozrywka i rekreacja & 110,0 & 154,5 & 94,1 & 118,8 & 190,0 \\
\hline Sekcja P - Edukacja & 122,2 & 109,1 & 100,0 & 108,3 & 144,4 \\
\hline Sekcja S - Pozostałe usługi & 112,5 & 122,2 & 109,1 & 108,3 & 162,5 \\
\hline RAZEM & 103,8 & 122,1 & 98,6 & 110,1 & 137,7 \\
\hline
\end{tabular}

Tabela 5. Dynamika branżowa kredytów Źródło: obliczenia własne na podstawie Raport o sytuacji banków w roku 2013, 2014, 2015. 


\begin{tabular}{|l|r|r|r|r|r|r|}
\cline { 2 - 7 } \multicolumn{1}{c|}{} & $11 / 10$ & $12 / 11$ & $13 / 12$ & $14 / 13$ & $15 / 14$ & $15 / 10$ \\
\hline Kredyty zagrożone & 107,4 & 108,7 & 99,7 & 101,7 & 99,5 & 117,8 \\
\hline Sektor finansowy & 50,0 & 100,0 & 200,0 & 150,0 & 66,7 & 100,0 \\
\hline Sektor niefinansowy & 107,5 & 108,6 & 99,7 & 101,5 & 99,7 & 117,9 \\
\hline Sektor budżetowy & 150,0 & 133,3 & 75,0 & 100,0 & 66,7 & 100,0 \\
\hline Gospodarstwa domowe & 113,2 & 102,6 & 99,0 & 98,0 & 101,6 & 114,4 \\
\hline Konsumpcyjne & 100,9 & 91,0 & 86,9 & 90,3 & 100,6 & 72,4 \\
\hline Mieszkaniowe & 153,1 & 120,0 & 116,7 & 104,8 & 98,2 & 220,4 \\
\hline Pozostałe & 128,3 & 119,5 & 110,9 & 104,9 & 106,5 & 190,0 \\
\hline Przedsiębiorstwa & 100,7 & 117,2 & 100,6 & 105,6 & 97,7 & 122,4 \\
\hline MSP & 105,9 & 109,7 & 99,1 & 105,2 & 100,4 & 121,6 \\
\hline Duże przedsiębiorstwa & 89,7 & 135,9 & 103,8 & 106,4 & 91,5 & 123,0 \\
\hline $\begin{array}{l}\text { Kredyty opóźnione } \\
\text { w spłacie }\end{array}$ & \multicolumn{7}{|l|}{} \\
\hline Konsumpcyjne & 102,2 & 101,1 & 91,5 & 95,3 & 95,1 & 85,7 \\
\hline do 30 dni & 103,6 & 90,8 & 89,9 & 89,2 & 93,7 & 70,6 \\
\hline$>30$ dni & \multicolumn{7}{|l|}{} \\
\hline Mieszkaniowe & 116,3 & 116,7 & 97,7 & 104,6 & 93,4 & 129,6 \\
\hline do 30 dni & 159,6 & 117,6 & 107,5 & 97,4 & 92,0 & 180,7 \\
\hline$>30$ dni
\end{tabular}

Tabela 6. Dynamika jakości portfela kredytowego (kredyty zagrożone)

Źródło: obliczenia własne na podstawie Raport o sytuacji banków w roku 2013, 2014, 2015.

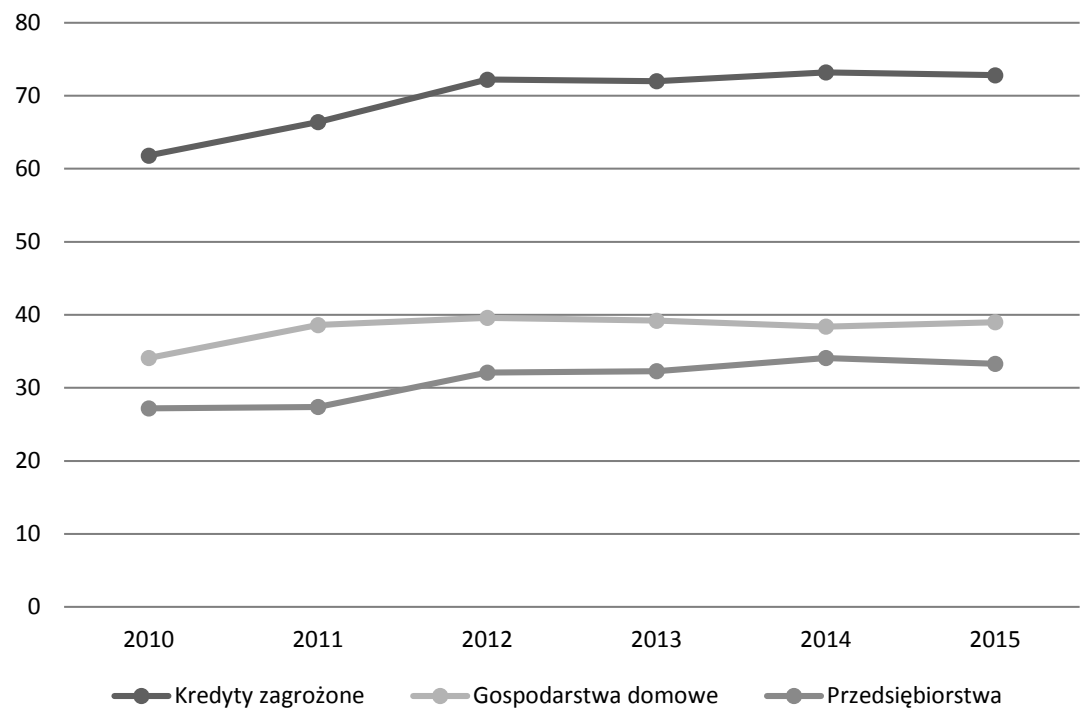

Rysunek 6. Kredyty zagrożone ogółem, dla gospodarstw domowych i przedsiębiorstw Źródło: opracowanie własne na podstawie Raport o sytuacji banków w roku 2013, 2014, 2015. 
Dobrą informacją jest spadek w 2015 roku w porównaniu z rokiem 2014 poziomu kredytów zagrożonych o 0,5\% (0,4 mld zł). Największy udział $\mathrm{w}$ portfelu kredytów zagrożonych miały kredyty konsumpcyjne (12\%), kredyty dla MSP (12\%) oraz pozostałe kredyty dla gospodarstw domowych (10\%). Według BIG infoMonitor od sierpnia 2015 r. do października 2016 r. liczba niesolidnych dłużników wzrosła z 1,25 mln do 1,74 mln osób.

\section{Ubezpieczenie kredytów}

Szybki rozwój cywilizacji, tempo życia oraz coraz większe potrzeby sprawiają, że zaciągając w banku kredyt chcielibyśmy uchronić siebie i swych najbliższych przed skutkami nieprzewidzianych zdarzeń losowych. Analiza danych pozwala stwierdzić, że przybywa kredytobiorców i niespłaconych kredytów, dlatego banki stosują coraz szerszy wachlarz zabezpieczeń udzielonych kredytów [Jaworski 2000]. W Polsce formę zabezpieczenia kredytu ustala bank w porozumieniu z kredytobiorcą, uwzględniając rodzaj kredytu, okres spłaty, stan majątkowy oraz status prawny kredytobiorcy. Jedną z takich form jest ubezpieczenie kredytu. Przedmiotem ubezpieczenia kredytu jest spłata zaciągniętych kredytów przyjętych do ubezpieczenia przez ubezpieczyciela. W ogólnych warunkach określa się przedmiot i zakres ubezpieczenia, wyłączenie odpowiedzialności, umowę generalną, przyjęcie należności kredytowej do ubezpieczenia, składkę i ochronę ubezpieczeniową, obowiązki ubezpieczającego oraz zasady ustalania i wypłaty odszkodowań [Bogacka-Kisiel 2000]. Zabezpieczenie kredytu bankowego przez wykupienie polisy ubezpieczeniowej zabezpiecza, w przypadku zdarzeń losowych, zarówno interesy banku jak i kredytobiorcy. Ubezpieczenia kredytów można podzielić na dwie grupy, ubezpieczenia obowiązkowe i dobrowolne. Do grupy ubezpieczeń obowiązkowych zaliczamy [www1]:

- ubezpieczenie pomostowe jest zawierane przez bank i na jego rzecz, występuje przy kredytach hipotecznych,

- ubezpieczenie niskiego (brakującego) wkładu własnego także dotyczy kredytów hipotecznych i jest oferowane, gdy kredytobiorca nie wnosi wcale lub wnosi bardzo niewielki wkład własny,

- ubezpieczenie nieruchomości.

Do ubezpieczeń dobrowolnych możemy zaliczyć:

- ubezpieczenie na wypadek śmierci (ubezpieczenie na życie),

- ubezpieczenie na wypadek trwałego inwalidztwa,

- ubezpieczenie na wypadek utraty pracy,

- ubezpieczenie na wypadek niezdolności do pracy. 
W przypadku podjęcia decyzji o ubezpieczeniu kredytu należy wnikliwie zapoznać się z warunkami umowy ubezpieczenia. Nie wszystkie umowy ubezpieczenia dają możliwość spłaty całości kredytu, a jedynie kilku kolejnych rat. W ostatnich latach obserwujemy wysoki wzrost zainteresowania ubezpieczeniem kredytu (tab. 7). W roku $2015 \mathrm{w}$ porównaniu do roku 2005 liczba zawieranych polis wzrosła trzynastokrotnie, co miało swoje przełożenie na liczbę odszkodowań. Należy pamiętać, że w latach tych znacznie wzrosła liczba pobranych kredytów. W okresie ostatnich dziesięciu lat w ubezpieczeniach kredytów, różnego rodzaju ryzyk finansowych oraz gwarancji ubezpieczeniowych obserwujemy silny rozwój (tab. 8).

\begin{tabular}{|l|r|r|r|r|r|r|r|}
\hline \multicolumn{1}{|c|}{ Wyszczególnienie } & 2005 & \multicolumn{1}{c|}{2010} & \multicolumn{1}{c|}{2011} & \multicolumn{1}{c|}{2012} & \multicolumn{1}{c|}{2013} & \multicolumn{1}{c|}{2014} & \multicolumn{1}{c|}{2015} \\
\hline Liczba polis w tys. & 105,0 & 535,0 & 564,0 & 612,0 & 535,0 & 1202,0 & 1400,0 \\
\hline $\begin{array}{l}\text { Składki przypisane brutto } \\
\text { W mln zł }\end{array}$ & 494,4 & 1571,0 & 1612,1 & 1500,8 & 1840,9 & 2111,7 & 1615,6 \\
\hline $\begin{array}{l}\text { Liczba odszkodowań i świadczeń } \\
\text { w tys. }\end{array}$ & 4,0 & 51,0 & 54,0 & 63,0 & 76,0 & 80,0 & 56,0 \\
\hline $\begin{array}{l}\text { Odszkodowania i świadczenia } \\
\text { wypłacone brutto w mln zł }\end{array}$ & 176,8 & 406,5 & 394,2 & 846,3 & 866,0 & 587,9 & 433,1 \\
\hline
\end{tabular}

Tabela 7. Ubezpieczenia kredytu; różnego ryzyka finansowego, gwarancja ubezpieczeniowa Źródło: opracowanie własne na podstawie Rocznika Statystycznego Rzeczypospolitej Polskiej 2013, 2015, 2016.

\begin{tabular}{|l|r|r|r|r|r|r|}
\hline \multicolumn{1}{|c|}{ Wyszczególnienie } & $11 / 10$ & $12 / 11$ & $13 / 12$ & $14 / 13$ & $15 / 14$ & $15 / 05$ \\
\hline Liczba polis w tys. & 105,4 & 108,5 & 87,4 & 224,7 & 116,5 & 1333,3 \\
\hline $\begin{array}{l}\text { Składki przypisane brutto } \\
\text { W mln zł }\end{array}$ & 102,6 & 93,1 & 122,7 & 114,7 & 76,5 & 326,8 \\
\hline $\begin{array}{l}\text { Liczba odszkodowań i świad- } \\
\text { Czeń w tys. }\end{array}$ & 105,9 & 116,7 & 120,6 & 105,3 & 70,0 & 1400,0 \\
\hline $\begin{array}{l}\text { Odszkodowania i świadczenia } \\
\text { wypłacone brutto w mln zł }\end{array}$ & 97,0 & 214,7 & 102,3 & 67,9 & 73,7 & 245,0 \\
\hline
\end{tabular}

Tabela 8. Dynamika ubezpieczenia kredytu; różnego ryzyka finansowego, gwarancja ubezpieczeniowa

Źródło: obliczenia własne na podstawie Rocznika Statystycznego Rzeczypospolitej Polskiej 2013, 2015, 2016.

\section{Podsumowanie}

Ubezpieczenie kredytów jest jedną z form minimalizacji ryzyka kredytowego, ale nie jest ona w stanie całkowicie wyeliminować ryzyka. Ta forma zabezpieczenia spłaty kredytu daje nam poczucie bezpieczeństwa 
finansowego. Niejednokrotnie świadomość tego, że w przypadku nieprzewidzianych zdarzeń losowych część rat lub całość kredytu zostanie spłacona z polisy jest warta poniesienia kosztów związanych z ubezpieczeniem kredytu. W ostatnich dziesięciu latach obserwujemy duże zainteresowanie kredytami, zwłaszcza wśród ludzi młodych. Niepokojącym zjawiskiem jest jednak duża liczba kredytów zagrożonych także wśród najmłodszych kredytobiorców. Łatwy dostęp do kredytów sprawia, że ubezpieczenia kredytów cieszą się dużym zainteresowaniem i są często stosowaną formą zabezpieczenia spłaty kredytu.

\section{Bibliografia}

Bogacka-Kisiel E. (red.) (2000), Usługi i procedury bankowe, Wydawnictwo Akademii Ekonomicznej im. Oskara langego we Wrocławiu, Wrocław.

Jaworski W.L., Krzyżkiewicz Z., Kosiński B. (2000), Banki rynek operacje polityka, Poltext, Warszawa.

Raport o sytuacji banków w 2015 r. (2016), Urząd Komisji Nadzoru Finansowego, Warszawa.

Rocznik Statystyczny Rzeczypospolitej Polskiej 2013, Zakład Wydawnictw Statystycznych, Warszawa.

Rocznik Statystyczny Rzeczypospolitej Polskiej 2015, Zakład Wydawnictw Statystycznych, Warszawa.

Rocznik Statystyczny Rzeczypospolitej Polskiej 2016, Zakład Wydawnictw Statystycz-

nych, Warszawa.

[www1] https://rf.gov.pl/vademecum-klienta/abc-ubezpieczen/Ubezpieczenia_kredytow_2868.

[www2] https://www.big.pl/rejestr-dluznikow.

[www3] https://www.stat.gov.pl.

\section{UBEZPIECZENIE JAKO FORMA ZABEZPIECZENIA KREDYTU}

Podstawą działalności banku jest osiąganie zysku, a jednym ze sposobów uzyskiwania dochodów jest udzielanie kredytów. W ostatnich latach obserwujemy duże zainteresowanie kredytami, które są obarczone ryzykiem. W celu minimalizacji ryzyka kredytowego banki stosują różne formy zabezpieczeń. Jedną z metod zabezpieczenia spłaty kredytu jest ubezpieczenie. Celem artykułu jest analiza sytuacji na rynku kredytowym i zwrócenie uwagi na jedną z form zabezpieczenia spłaty 
kredytów jaką jest ubezpieczenie. Ubezpieczenia kredytów cieszą się dużym zainteresowaniem i są często stosowaną formą zabezpieczenia spłaty kredytu. Ze względu na dużą liczbę zaciąganych kredytów oraz pojawiające się problemy z ich spłatą, słusznym wydało się podjęcie takiego tematu badawczego.

Słowa kluczowe: kredyt, ubezpieczenie, zabezpieczenie kredytów.

\section{INSURANCE AS A FORM OF COLLATERAL}

The main activity of the bank is to gain profit and one way of earning an income is granting credits. In recent years we have seen a great interest in loans that incur risk. In order to minimize credit risk, banks use different forms of collateral. This article aims to analyze the current situation on the credit market and to draw attention to credit insurance as one possible form collateral. Credit insurance is a very popular and often used form of loan collateral. Due to the large number of credits taken and emerging problems with repayment, pursuing this research topic seems justified.

Keywords: credit, collateral for loans, insurance. 